\title{
PENGARUH MODEL PEMBELAJARAN ROLE PLAYING BERBANTUAN MEDIA VIDEO TERHADAP HASIL BELAJAR KOGNITIF SISWA SD
}

\author{
Riya Wulandari ${ }^{11}$, Angelia Timara ${ }^{1)}$, Emi Sulistri ${ }^{1}$, Sumarli1) \\ 1)Departemen Pendidikan Guru Sekolah Dasar, STKIP Singkawang, Singkawang, Kalimantan Barat, Indonesia \\ Corresponding author : Emi Sulistri \\ E-mail : sulistriemi@gmail.com
}

Diterima 25 Oktober 2021, Disetujui 05 November 2021

\begin{abstract}
ABSTRAK
Penelitian ini bertujuan untuk mengetahui pengaruh model pembelajaran Role Playing berbantuan media video terhadap hasil belajar kognitif siswa pada materi bunyi. Penelitian dilaksanakan di SD Swasta Torsina III Singkawang. Jenis penelitian yaitu penelitian kuantitatif dengan metode quasi experimental, dalam bentuk Nonequivalent Pre-test and Post-test Control Group Design. Populasi dalam penelitian ini adalah seluruh siswa kelas IV SD Torsina III Singkawang. Sampel diambil menggunakan teknik non probability dengan jenis sampling jenuh. Teknik pengumpulan data menggunakan teknik tes berupa tes objektif materi bunyi dan teknik non tes berupa angket respon. Hasil penelitian menunjukkan bahwa: (1) terdapat perbedaan hasil belajar ranah kognitif antara siswa yang diterapkan model pembelajaran role playing berbantuan media video dengan siswa yang mendapatkan pembelajaran langsung; (2) Penggunaan model pembelelajaran role playing berbantuan media video berpengaruh tinggi terhadap hasil belajar kognitif siswa; (3) Respon siswa positif terhadap model pembelajaran role playing berbantuan media video pada kategori baik.
\end{abstract}

Kata kunci: model pembelajaran role playing; media video; hasil belajar kognitif.

\section{ABSTRACT}

This study aims to determine the effect of the video media-assisted Role Playing learning model on students' cognitive learning outcomes on sound material. The research was conducted at Torsina III Private Elementary School, Singkawang. The type of research is quantitative research with quasiexperimental method, in the form of Nonequivalent Pre-test and Post-test Control Group Design. The population in this study were all fourth grade students of SD Torsina III Singkawang. Samples were taken using a non-probability technique with saturated sampling type. The data collection technique used a test technique in the form of an objective test of sound material and a non-test technique in the form of a response questionnaire. The results showed that: (1) there were differences in cognitive domain learning outcomes between students who applied the role playing learning model assisted by video media and students who received direct learning; (2) The use of role playing learning models assisted by video media has a high effect on students' cognitive learning outcomes; (3) Positive student responses to the video-assisted role playing learning model in the good category.

Keywords: role playing learning model; video media; cognitive learning outcomes.

\section{PENDAHULUAN}

IPA merupakan ilmu yang berkaitan dengan alam dan lingkungan sekitar. Menurut (Darmojo dan Kaligis, 2002) "IPA adalah pengetahuan manusia tentang alam semesta yang benar dalam arti rasional dan objektif". Benar dalam arti rasional artinya sesuai dengan logika atau masuk akal dan objektif artinya dapat diuji kebenarannya secara ilmiah, tidak hanya berdasarkan pendapat seseorang saja tanpa dapat diamati kebenarannya oleh alat indera ataupun dengan eksperimeneksperimen tertentu. Pada mata pelajaran IPA siswa diharapkan dapat mengetahui pengetahuan alam dalam kehidupan sehari-hari, pembelajaran IPA ini membutuhkan keterampilan, kreatifitas dan pemahaman dalam pelaksanaan belajarnya. Pembelajaran IPA dikatakan berhasil apabila semua tujuan pembelajaran yang telah ditentukan dapat tercapai, yang terungkap dalam hasil belajar IPA.

Menurut (Mariana et al., 2009) Pentingnya pelajaran IPA di SD yaitu menjadikan siswa untuk berpikir secara positif yang memberikan dampak baik sehingga siswa menjadi tahu tentang teknologi dan ramah lingkungan sebagai elaborasi dari membaca materi tentang pelajaran IPA. Pembelajara IPA di SD merupakan wahana untuk membekali 
siswa dengan pengetahuan keterampilan dan sikap yang diperlukan untuk melanjutkan pendidikan dan untuk menyesuaikan diri dengan perubahan-perubahan disekelilingnya. Pembelajaran IPA pada anak SD juga mengajarkan cara memecahkan masalah, melatih kemampuan pemahaman, mengambil kesimpulan, melatih bersikap objektif, bekerja sama dan menghargai pendapat orang lain. Salah satu kemampuan yang perlu diperhatikan pada pembelajaran IPA adalah hasil belajar kognitif. Menurut (Purwanto, 2010) Setelah mengikuti pembelajaran siswa mengalami perubahan dalam kemampuan kognitif, afektif dan psikomotor, tergantung dari tujuan pengajarannya. Menurut (Anderson \& Krathwohl, 2010) hasil belajar terdiri dari 3 ranah yaitu, ranah kognitif, ranah afektif, dan pisikomotorik. Ranah kognitif terdiri dari mengingat (remember), memahami (understand), mengaplikasikan (apply), menganalisis (analyze), mengevaluasi (evaluate), mencipta (create). Ranah afektif terdiri dari (menerima, merespon, menilai, mengatur, dan karakteristik dengan suatu nilai atau komolek nilai). Rranah psikimotorik terdiri dari (produktif, fisik, sosial dan intelektual).

Pentingnya ranah kognitif bagi siswa dalam pembelajaran IPA yaitu menjadi suatu wadah bagi siswa dalam mempelajari diri sendiri dan alam sekitar, sehingga dapat bermanfaat dalam kehidupan bermasyarakat siswa. Hasil belajar IPA berdasarkan dari segi produk, proses, dan sikap keilmuan. Dari segi produk siswa diharapkan dapat memahami konsep-konsep IPA dan keterkaitannya dengan kehidupan sehari-hari, dari segi proses diharapkan siswa dapat memiliki kemampuan untuk mengembangkan pengetahuan, gagasan dan menerapkan konsep yang diperolehnya untuk menjelaskan dan memecahkan masalah yang ditemukan dalam kehidupan sehari-hari, dan dari segi sikap diharapkan siswa mempunyai minat untuk mempelajari bendabenda di lingkungannya, bersikap ingin tahu, kritis, bertanggung jawab dapat bekerjasama dan mandiri.

Kenyataannya hasil belajar kognitif IPA siswa masih rendah, hal ini terbukti dari observasi awal yang dilakukan pada bulan April tahun 2021 di salah satu SD Swasta di Singkawang, diperoleh data hasil tugas siswa kelas IV pada mata pelajaran IPA masih rendah dan ada yang di bawah KKM yaitu masih berkisar 20-67. KKM hasil belajar kognitif siswa kelas IV pada mata pelajaran IPA yaitu 70 . Saat melakukan wawancara dengan guru kelas IV, guru menyatakan bahwa siswa masih banyak yang belum paham tentang pelajaran IPA, guru tersebut juga menjelaskan bahwa beberapa siswa tidak semangat dan antusias pada materi yang diajarkan. Disamping itu juga kurangnya respon siswa saat proses pembelajaran berlangsung karena pembelajaran hanya berpusat pada guru. Siswa cenderung hanya mencatat yang telah diberikan oleh guru supaya bisa menjawab soal-soal yang nantinya akan diujikan. Tentu saja hal ini akan mempengaruhi hasil belajar siswa. Hal tersebut perlu mendapat perhatian yang lebih agar selalu menciptakan suasana kelas yang kondusif, menarik dan tidak membosankan untuk siswa sehingga siswa menjadi lebih semangat dan aktif dalam pembelajaran. Kondisi seperti ini dapat diatasi dengan menerapkan model pembelajaran yang tepat untuk pembelajaran IPA. Pada pembelajaran IPA banyak model-model pembelajaran yang bisa digunakan pada proses pembelajarannya. Salah satunya yang dapat diterapkan adalah model pembelajaran role playing.

Menurut (Imas dan Berlin, 2015), role playing yaitu cara penguasaan bahan-bahan pelajaran melalui pengembangan imajinasi dan penghayatan siswa terhadap materi. Pengembangan dan penghayatan imajinasi dilakukan oleh siswa dengan memerankannya sebagai tokoh hidup atau benda mati. Permainan ini pada umumnya dilakukan lebih dari satu orang, bergantung pada apa yang diperankan. Kelebihan model ini adalah seluruh siswa dapat berpartisipasi dan mempunyai kesempatan untuk menguji kemampuannya dalam bekerja sama. Sedangkan menurut (Hidayati, 2002) model role playing dapat melibatkan aspek kognitif meliputi pemecahan masalah dalam proses pembelajaran, dengan role playing siswa yang awalnya pasif dapat aktif, sehingga siswa berminat lagi pada pembelajaran IPA.

(Aris, 2014), langkah-langkah pokok pembelajaran role playing yaitu, guru memilih situasi bermain peran, mempersiapkan kegiatan bermain peran, memilih peserta atau pemain peran, mempersiapkan penonton, memilih peran (melaksanakan kegiatan bermain peran), mendiskusikan dan mengevaluasi kegiatan bermain peran. Kekurangan model pembelajaran role playing adalah membutuhkan waktu yang relatif panjang atau banyak dan membutuhkan kreativitas atau daya kreasi yang tinggi dari pihak guru maupun siswa, sehingga memilih media video untuk menyempurnakan model pembelajaran role playing karena dengan menggunakan bantuan media video langkahlangkah dalam pelaksanaan akan menjadi teratur membantu penyampaian suatu materi pembelajaran dan waktu yang diperlukan menyesuaikan dengan proses pembelajaran di 
kelas. Menurut (Azhar, 2013) menyatakan media video merupakan bentuk media pembelajaran yang murah dan terjangkau, video dapat menggambarkan suatu proses secara tepat dan dapat dilihat secara berulangulang, dapat mendorong motivasi siswa untuk tetap melihatnya dan meningkatkan pemahaman siswa secara nyata tentang materi yang akan diajarkan.

Penelitian yang dilakukan oleh (Adriana, 2016) bahwa dengan menggunakan model pembelajaran kooperatif dengan tipe role playing terdapat pengaruh terhadap minat dan hasil belajar IPA siswa kelas IV SD Inpres Dekai Kabupaten Yahukimo. Hasil penelitian lain oleh (Juminten dan Siregar, 2019) bahwa dengan menggunakan metode pembelajaran role playing terdapat peningkatan keaktifan belajar IPA dan hasil belajar IPA pada materi pertumbuhan makhluk hidup siswa kelas VI SD YPPK Santo Petrus. Penelitian lain yang dilakukan oleh (Linda et al., 2019) bahwa terdapat pengaruh penggunaan media video terhadap hasil belajar subtema 1 keberagaman budaya bangsaku siswa SD. Berdasarkan hasil penelitian tersebut dapat disimpulkan bahwa model pembelajaran role playing memiliki pengaruh yang signifikan terhadap hasil belajar siswa. Pada penelitian ini terdapat perbedaan pada materi IPA yang digunakan, yaitu materi bunyi sedangkan indikator hasil belajar ranah kognitif yang digunakan yaitu mengingat, memahami, mengaplikasikan dan menganalisis serta ada penambahan media video dalam penelitian. Adapun tujuan khusu penelitian ini adalah untuk mendeskripsikan ada tidaknya pengaruh model pembelajaran Role Playing berbantuan media video terhadap hasil belajar kognitif siswa pada materi bunyi kelas IV SD. Adapun tujuan umum yaitu: 1) untuk mengidentifikasi untuk mengidentifikasi perbedaan hasil belajar kognitif siswa kelas IV yang menggunakan model pembelajaran Role Playing berbantuan media video dengan model pembelajaran langsung pada materi bunyi siswa kelas IV SD; 2) untuk mengidentifikasi seberapa besar pengaruh model pembelajaran Role Playing berbantuan media video terhadap hasil belajar kognitif siswa kelas IV SD; 3) Untuk mengidentifikasi persentase respon siswa terhadap model pembelajaran Role Playing berbantuan media video kelas IV.

\section{METODE PENELITIAN}

Metode dalam penelitian ini eksperimen semu (quasi experimental design). Menurut (Sugiyono, 2018) desain penelitian ini mempunyai kelompok kontrol, tetapi tidak dapat berfungsi sepenuhnya untuk mengontrol variabel-variabel luar yang mempengaruhi eksperimen. Model ini digunakan untuk menguji hipotesis yang behubungan sebab akibat melalui perlakuan dan menguji perubahan yang diakibatkan oleh perlakuan tersebut.

$$
\text { Pada penelitian ini, peneliti }
$$
menggunakan desain penelitian Nonequivalent Pre-test and Post-test Control Group Design, desain ini terdapat dua sampel yaitu kelas eksperimen dan kelas kontrol tidak dipilih secara random. Pada penelitian desain ini terdapat dua kelas yaitu kelas eksperimen dan kelas kontrol. Pada kelas eksperimen diberikan perlakuan menggunakan model pembelajaran role playing berbantuan media video dan pada kelas kontrol metode konvensional (langsung). Sebelum diberikan perlakuan pada kedua kelas akan dibandingkan hasil belajarnya terlebih dahulu dengan memberikan pretest untuk mengetahui keadaan awal, adakah perbedaan pada kedua kelas tersebut. Selanjutnya, setelah diberikan perlakuan diberikan posttest untuk melihat hasil perbedaan setelah diberikan perlakuan. Populasi dalam penelitian ini adalah seluruh siswa kelas IV di SD Swasta Torsina III Singkawang yang berjumlah 56 orang siswa, terdiri dari dua kelas IVA dan IVB. Teknik pengambilan sampel dalam penelitian ini adalah non probability dengan jenis sampel jenuh (total sampling). Menurut (Sugiyono, 2018) sampel jenuh (total sampling) adalah penetapan jumlah sampel dengan cara mengambil atau menggunakan semua populasi untuk dijadikan sampel, dengan catatan populasi kurang dari 100. Sampel penelitian ini adalah kelas IV A dan IV B dengan jumlah peserta didik 56 orang. Kelas yang terpilih sebagai kelas eksperimen adalah kelas IV B yang berjumlah 28 siswa, sedangkan kelas yang terpilih sebagai kelas kontrol adalah kelas IV A dengan jumlah 28 siswa.

Teknik pengumpulan data yang digunakan dalam penelitian ini adalah teknik tes dan non tes. Tes yang dilakukan menggunakan instrumen berupa soal objektif atau pilihan ganda mengenai materi bunyi. Tes ini diberikan kepada dua kelas yaitu pada kelas kontrol dan kelas eksperimen pada saat penelitian berupa prettest dan posttest. Tes dilakukan untuk mengetahui hasil belajar ranah kognitif IPA. Teknik non tes yang digunakan dalam penelitian ini dengan memberikan lembar angket respon siswa yang betujuan untuk mengetahui respon siswa terhadap model pembelajaran role playing. Teknik analisis data yang digunakan dalam penelitian ini adalah 1) uji t dua sampel berkolerasi; 2) Effect Size; 3) persentase respon siswa. 
HASIL DAN PEMBAHASAN

Hasil Penelitian

Deskripsi Pengaruh Hasil Belajar Kognitif

Berdasarkan hasil dari pengumpulan data yang telah dilakukan, maka didapatkan data hasil Pre-test dan Post-test berupa ratarata, standar deviasi, skor tertinggi, skor terendah, dan jumlah siswa pada kelas kontrol dan eksperimen. Untuk selengkapnya dapat disajikan pada Tabel 1.

Tabel 1. Perbedaan Nilai Kelas Kontrol dan Eksperimen.

\begin{tabular}{ccc}
\hline Kriteria & Kontrol & Eksperimen \\
\hline Rata-rata & 53.64286 & 70.17857143 \\
\hline $\begin{array}{c}\text { Standar } \\
\text { Deviasi }\end{array}$ & 18.35136199 & 15.30445002 \\
\hline $\begin{array}{c}\text { Skor } \\
\text { Tertinggi }\end{array}$ & 85 & 95 \\
\hline $\begin{array}{c}\text { Skor } \\
\text { Terendah }\end{array}$ & 30 & 30 \\
\hline $\begin{array}{c}\text { Jumlah } \\
\text { Siswa }\end{array}$ & 28 & 28 \\
\hline
\end{tabular}

Berdasarkan Tabel 1 diperoleh data nilai kelas kontrol 53.64286 standar deviasi sebesar 18.35136199, skor tertinggi 85 dan terendah 30. Sedangkan nilai kelas eksperimen diperoleh nilai rata-rata 70.17857143 , standar deviasi sebesar 15.30445002, nilai tertinggi sebesar 95 dan nilai terendah 30 .

\section{Perbedaan Hasil Belajar Kognitif Siswa Kelas IV Yang Menggunakan Model Pembelajaran Role Playing Berbantuan Media Video Dengan Pembelajaran Langsung}

\section{a. Uji Normalitas}

Uji normalitas dilakukan untuk mengetahui apakah data Post-test yang telah dikumpulkan berasal dari populasi yang berdistribusi normal atau tidak. Hasil uji normalitas data Post-test hasil belajar siswa kelas eksperimen dan kelas kontrol dapat dilihat pada Tabel 2.

Tabel 2. Hasil Perhitungan Uji Normalitas Data

\begin{tabular}{lcc}
\hline \multirow{2}{*}{ Statistika } & \multicolumn{2}{c}{ Kelas } \\
\cline { 2 - 3 } $\mathrm{X}^{2}$ hitung & Eksperimen & Kontrol \\
\hline Jumlah Siswa $(\mathrm{n})$ & 28 & 2.759 \\
\hline Taraf Kesukaran & $5 \%$ & 28 \\
\hline $\mathrm{X}^{2}$ tabel & 7.814 & 7.814 \\
\hline Keputusan & \multicolumn{2}{c}{ Ho diterima } \\
\hline Kesimpulan & \multicolumn{2}{c}{ Normal } \\
\hline
\end{tabular}

Berdasarkan Tabel 2 terlihat hasil perhitungan uji normalitas data pada kelas eksperimen di dapatkan terlihat $\mathrm{x}^{2}$ hitung 7.539 dan $x^{2}$ tabel adalah 7.814 karena $x^{2}$ hitung $\leq x^{2}$ tabel yaitu $7.539 \leq 7.814$ maka data berdistribusi normal. Sedangkan hasil perhitungan kelas kontrol didapatkan $x^{2}$ hitung 2.759 dan $x^{2}$ tabel adalah 7,814. Karena $x^{2}$ hitung $\leq x^{2}$ tabel $2.759 \leq$ 7,814 maka data berdistribusi normal. Karena data kelas eksperimen dan kontrol berdistribusi normal, Ho diterima dan data berdistribusi normal, maka untuk menentukan homogenitas data menggunakan rumus $f$.

\section{b. Uji homogenitas data menggunakan rumus $f$}

Setelah data skor post-test kelas eksperimen dan kelas kontrol dihitung dan didapatkan data tersebut berdistribusi normal, selanjutnya akan melakukan uji homogenitas data menggunakan rumus f. Adapun hasil perhitungan uji homogenitas data dapat dilihat pada tabel 3.

Tabel 3. Hasil Perhitungan Uji Homogenitas

\begin{tabular}{lcc}
\hline \multirow{2}{*}{ Statistik } & \multicolumn{2}{c}{ Kelas } \\
\cline { 2 - 3 } & Eksperimen & Kontrol \\
\hline Varians $\left(s^{2}\right)$ & \multicolumn{2}{c}{1,426} \\
\hline $\mathrm{f}_{\text {hitung }}$ & 28 & 28,22 \\
\hline Jumlah siswa $(\mathrm{n})$ & $5 \%$ & $5 \%$ \\
\hline Taraf kesukaran & \multicolumn{2}{c}{$5 \%$} \\
$(\alpha)$ & \multicolumn{2}{c}{1,90} \\
\hline $\mathrm{f}_{\text {tabel }}$ & \multicolumn{2}{c}{ H Diterima } \\
\hline Keputusan & \multicolumn{2}{c}{ Homogen } \\
\hline Kesimpulan & \multicolumn{2}{c}{}
\end{tabular}

Berdasarkan Tabel 3 terlihat bahwa perhitungan data menggunakan rumus $f$. Diketahui varians kelas eksperimen yaitu 334,16 menjadi varians terbesar, sedangkan varians kelas kontrol adalah 234,22 menjadi varians terkecil sehingga fhitung adalah 1,426. Dari $f_{\text {tabel }}$ dengan $\alpha=5 \%$ dan diperoleh $f_{\text {tabel }}=$ 190. Karena $f_{\text {hitung }} \leq f_{\text {tabel }}$ yaitu $1,426 \leq 1,90$ maka kelas eksperimen dan kelas kontrol mempunyai varians yang sama atau homogen. Karena data nilai pada kelas eksperimen dan kelas kontrol berdistribusi normal dan homogen, maka selanjutnya dilakukan uji t dua sampel untuk mengetahui apakah terdapat pengaruh hasil belajar kognitif siswa antara kelas yang diberikan model pembelajaran Role Playing berbantuan media video dengan kelas yang diberikan pembelajaran langsung pada materi bunyi kelas IV SD Swasta Torsina III Singkawang.

\section{c. Hipotesis Menggunakan Uji t Dua Sampel Berkolerasi}

Berdasarkan uji normalitas dan homogenitas diperoleh bahwa data pretest dan Post-test kelas eksperimen dan kelas kontrol berdistribusi normal dan mempunyai varians yang sama homogen. Maka untuk menguji kesamaan rata-rata kedua kelas menggunakan uji t dua sampel, yaitu jika thitung $\leq t_{\text {tabel }}$ tidak 
terdapat perbedaan hasil belajar kognitif kelas yang diberikan model pembelajaran role plyaing berbantuan media video dengan pembelajaran langsung pada materi bunyi kelas IV SD. Jika thitung $>$ tabel terdapat perbedaan hasil belajar kognitif kelas yang diberikan model pembelajaran role plyaing berbantuan media video dengan pembelajaran langsung pada materi bunyi kelas IV SD. Diketahui thitung $=11,35$ dan tabel $=2,004$ diperoleh thitung $>t_{\text {tabel }}=11,35>2,004$ maka $\mathrm{Ha}$ diterima dan Ho ditolak. Sehingga dapat disimpulkan bahwa terdapat pengaruh model pembelajaran role playing berbantuan media video terhadap hasil belajar kognitif siswa pada materi bunyi. Selanjutnya untuk melihat seberapa pengaruh model pembelajaran role playing berbantuan media video terhadap hasil belajar kognitif siswa pada materi bunyi, maka digunakan rumus Effect Size.

\section{Besar Pengaruh Model Pembelajaran Role Playing Berbantuan Media Video Terhadap Hasil Belajar Kognitif Siswa Pada Materi Bunyi}

Setelah dilakukan uji t diperoleh hasil model pembelajaran role playing berbantuan media video berpengaruh terhadap hasil belajar kognitif siswa. Selanjutnya untuk mengetahui seberapa besar pengaruh model pembelajaran role playing berbantuan media video terhadap hasil belajar kognitif siswa pada materi bunyi, maka digunakan rumus Effect Size (ES). Hasil uji Effect Size disajikan pada tabel 4.

Tabel 4. Rekapitulasi Hasil Uji Effect Size

\begin{tabular}{lll}
\hline Kelas & $\begin{array}{l}\text { Nilai Rata- } \\
\text { rata }\end{array}$ & $\begin{array}{l}\text { Standar } \\
\text { Deviasi Kelas } \\
\text { kontrol }\end{array}$ \\
\hline Eksperimen & 70,17 & 15,30 \\
Kontrol & 53,64 & 18,28 \\
\hline ES & \multicolumn{3}{c}{$\mathbf{0 , 9 0}$} \\
Kriteria & \multicolumn{2}{c}{ Tinggi } \\
\hline
\end{tabular}

Berdasarkan Tabel 4 diketahui bahwa pengaruh model pembelajaran role playing berbantuan media video terhadap hasil belajar kognitif siswa sebesar 0,90 berada pada sehingga kategori tinggi dengan rentang $E S>$ 0,8 .

\section{Angket Respon Siswa}

Angket respon siswa dalam penelitian ini merupakan angket yang hanya diberikan kepada siswa kelas eksperimen untuk mengetahui apakah terdapat respon positif siswa terhadap model pembelajaran role playing berbantuan media video. Angket respon siswa yang digunakan berupa pernyataan positif dan pernyataan negatif yang berjumlah 20 pernyataan dan terdiri dari 4 indikator respon siswa, yaitu: (1) Relevansi, (2) Perhatian, (3) Kepuasan, dan (4) Percaya Diri. Siswa hanya diminta untuk memberikan tanda check list $(\sqrt{ })$ pada salah satu dari dua pilihan yang disediakan yaitu YA dan TIDAK. Adapun hasil persentase angket respon siswa sesuai indikator penilaian disajikan pada Tabel 5 .

Tabel 5. Rekapitulasi Indikator Respon Siswa

\begin{tabular}{llll}
\hline No & Indikator & Persentase & Kriteria \\
\hline 1. & Relevansi & $64 \%$ & Baik \\
\hline 2. & Perhatian & $70 \%$ & Baik \\
\hline 3. & Kepuasan & $75 \%$ & Baik \\
\hline 4. & $\begin{array}{l}\text { Percaya } \\
\text { Diri }\end{array}$ & $77 \%$ & $\begin{array}{l}\text { Sangat } \\
\text { Baik }\end{array}$ \\
\hline & Rata-rata & $\mathbf{7 1 , 5 \%}$ & Baik \\
\hline
\end{tabular}

Berdasarkan Tabel 5, siswa yang menjawab YA sebanyak 434 dengan aspek indikator relevansi $64 \%$, perhatian $70 \%$, kepuasan $75 \%$, dan $77 \%$ sehingga mendapatkan kategori baik dengan persentase rata-rata $71,5 \%$ dengan rentang $50 \% \leq X \leq 75 \%$.

\section{Pembahasan}

Terdapat Perbedaan Hasil Belajar Kognitif Siswa Kelas IV Yang Menggunakan Model Pembelajaran Role Playing Berbantuan Media Video Dengan Pembelajaran Langsung

Berdasarkan hasil penelitian yang dilakukan di SD Swasta Torsina III Singkawang pada tanggal 4-6 Agustus 2021, peneliti melakukan penelitian di SD Swasta Torsina III singkawang yang terdiri dari 28 siswa kelas eksperimen. Peneliti memberikan soal Pre-test terlebih dahulu sebelum menggunakan model role playing berbantuan media video. Setelah diterapkannya model pembelajaran role playing berbantuan media video peneliti memberikan post-test untuk melihat perbedaan nilai ratarata sebelum dan sesudah diterapkannya model pembelajaran role playing berbantuan media video dengan pembelajaran langsung terhadap hasil belajar kognitif siswa pada materi bunyi. Setelah data didapatkan kemudian dianalisis menggunakan uji prasyarat yaitu uji normalitas dan uji hipotesis menggunakan uji t, maka diperoleh hasil terdapat perbedaan hasil belajar kognitif siswa antara kelas yang menggunakan model pembelajaran role playing berbantuan media video dengan pembelajaran langsung.

Pada kelas eksperimen peneliti membagi kegiatan menjadi beberapa langkah sesuai dengan tahapan model pembelajaran role playing, langkah pertama peneliti menampilkan video tentang materi bunyi siswa mengamati video yang di tayangkan, hal ini melatih siswa untuk dapat mengingat dan 
memahami kembali tentang apa saja yang sudah dijelaskan dalam video hal. Langkah kedua peneliti membagi siswa menjadi beberapa kelompok yang terdiri dari 5 orang siswa dalam setiap kelompoknya dimana dalam sebuah kelompok tersebut siswa yang memiliki kemampuan tinggi diacak kesemua kelompok agar siswa yang memiliki kemampuan rendah dapat berdiskusi dengan siswa yang memiliki kemampuan tinggi, peneliti sudah mempersiapkan masalah yaitu tentang materi bunyi selanjutnya proses pemilihan peran oleh masing-masing kelompok siswa. Langkah ke tiga menyusun tahap bermain peran, yaitu peneliti memberikan penjelasan tahapan bermain peran siswa memahami setiap penjelasan yang diberikan oleh peneliti. Langkah ke empat peneliti menyiapkan pengamat dari setiap kelompok yang sudah dipilih, yaitu siswa yang bertugas sebagai pengamat diminta untuk mencatat kembali halhal yang penting untuk dibahas. Langkah ke lima pemeranan, masing-masing kelompok siswa secara bergantian memerankan skenario yang sudah dipersiapkan pada tahap ini adalah siswa mengaplikasikan tentang materi bunyi. Langkah ke enam memberi poin dan evaluasi, setelah siswa melakukan pemeranan peneliti memberikan poin dan mengevaluasi pada setiap kelompok yang tampil. Langkah ke tujuh pengambilan kesimpulan dari bermain peran yang telah dilakukan siswa yang bertugas sebagai kelompok pengamat mempersentasekan hasil kesimpulan dari apa yang sudah diperan kan oleh kelompok pemeran.

Menurut Kurniasih (2015), bermain peran (Role Playing) yaitu cara penguasaan bahanbahan pelajaran melalui pengembangan imajinasi dan penghayatan siswa terhadap materi. Pengembangan dan penghayatan imajinasi dilakukan oleh siswa dengan memerankannya sebagai tokoh hidup atau benda mati. Hamzah (2014), pembelajaran role playing merupakan landasan praktik pembelajaran hasil penurunan teori psikologi pendidikan dan belajar, yang dirancang berdasarkan proses analisis yang diarahkan pada implemntasi kurikulum dan implikasinya pada tingkat operasional didepan kelas. Salah satu pembelajaran yang dapat digunakan dalam kegiatan pembelajaran adalah model role playing. Role Playing merupakan suatu model pembelajaran, dimana peserta didik diminta untuk memainkan peran tertentu. Menurut Sutikno (2014), pengalaman belajar yang diperoleh dari model ini meliputi kemampuan kerja sama, komunikatif, dan menginterprestasikan suatu kejadian.

\section{Model Pembelajaran Role Playing Berbantuan Media Video Berpengaruh Besar Terhadap Hasil Belajar Kognitif Siswa Pada Materi Bunyi}

Berdasarkan hasil penelitian dengan menggunakan model pembelajaran role playing berbantuan media video memberikan pengaruh yang tinggi terhadap hasil belajar kognitif siswa. Hal ini disebabkan karena pada saat menggunakan model pembelajaran role playing dapat membangkitkan semangat siswa dan berkesan tahan lama dalam ingatan siswa. Sejalan dengan hasil penelitian Ardi (2016), yang menyatakan terdapat pengaruh penerapan metode role playing terhadap minat dan hasil belajar siswa sebesar 0,929.

Berdasarkan hasil perhitungan seberapa besar pengaruh model pembelajaran role playing berbantuan media video dari kriteria Effect Size yang didapat maka terdapat pengaruh yang tinggi pada model pembelajaran role playing berbantuan media video terhadap hasil belajar kognitif siswa sebesar 0,90 berada dalam kategori tinggi dengan kriteria $E S>0,8$. Sutikno (2014), menjelaskan model role playing membuat siswa mampu bekerja sama dan komunikatif sehingga pembelajaran dengan role playing berpengaruh mengembangkan pemikiran siswa secara individu karena merangsang kemampuan siswa.

\section{Respon Siswa Positif Terhadap Model Pembelajaran Role Playing Berbantuan Media Video}

Hasil analisis respon siswa terhadap pembelajaran IPA dengan menggunakan model pembelajaran role playing berbantuan media video menunjukkan tanggapan yang positif. Hal ini ditunjukkan dari hasil perolehan rata-rata hasil persentase keseluruhan angket respon siswa dengan persentase $71,5 \%$ dengan kriteria baik.

Kriteria diukur untuk mengetahui respon siswa terhadap model pembelajaran role playing berbantuan media video dengan 4 indikator dan dikembangkan menjadi pernyataan positif dan negatif. Berdasarkan hasil analisis tanggapan respon siswa terhadap indikator relevansi yang berkaitan dengan pengalaman belajar siswa dan menghubungkan materi dengan kehidupan sehari-hari siswa dengan menggunakan model pembelajaran role playing berbantuan media video. Pada indikator perhatian berkaitan dengan kemenarikan model pembelajaran role playing berbantuan media video, dalam hal ini proses pembelajaran dibuat semenarik mungkin agar mendapatkan perhatian dari siswa. Pada hasil indikator kepuasan berkaitan 
dengan perasaan siswa tentang pengalaman belajar siswa, seperti perasaan senang saat penyampaian materi bunyi menggunakan model pembelajaran role playing berbantuan media video. Pada hasil analisis indikator percaya diri berkaitan dengan harapan siswa setelah mengunakan model pembelajaran role playing berbantuan media video. Sejalan dengan pendapat Ardi (2016), pembelajaran menyenangkan menyebabkan tumbuh respon yang positif dari siswa yang secara langsung berdampak pada peningkatan hasil belajar siswa. Dapat disimpulkan bahwa model pembelajaran role playing berbantuan media video pada materi bunyi berpengaruh positif terhadap hasil belajar kognitif siswa.

\section{SIMPULAN DAN SARAN Simpulan}

Berdasarkan hasil perhitungan data penelitian dan pembahasan secara umum dapat disimpulkan bahwa terdapat pengaruh model pembelajaran Role Playing berbantuan media video terhadap hasil belajar kognitif siswa pada materi bunyi. Sesuai dengan subsub masalah penelitian, maka secara khusus dapat disimpulkan sebagai berikut: 1) Terdapat perbedaan hasil belajar kognitif siswa antara kelas yang diberikan model pembelajaran role playing berbantuan media video dengan kelas yang diberikan model pembelajaran langsung pada materi bunyi di kelas IV, dengan thitung = $11,35>$ tabel $=2,004$. 2) Model pembelajaran role playing berbantuan media video berpengaruh besar terhadap hasil belajar kognitif siswa dengan hasil uji Effect Size sebesar 0,90 berada pada kategori tinggi. 3) Respon siswa positif terhadap model pembelajaran role playing berbantuan media video dengan persentase sebesar $71,5 \%$ pada kategori baik.

\section{Saran}

Berdasarkan hasil penelitian yang telah didapatkan, ada beberapa kendala dalam proses penelitian yang dilakukan selama masa pandemi COVID-19 ini. Maka dari itu saran dalam penelitian ini adalah: 1) Peneliti selanjutnya sebaiknya memperhatikan waktu selama proses penelitian berlangsung karena waktu didalam RPP tidak sesuai dengan waktu yang sudah ditentukan dilapangan karena masa pandemi covid-19 sehingga proses penelitian di sekolah diberikan batasan waktu. 2) Bagi peneliti selanjutnya yang ingin melakukan penelitian seperti ini diharapkan mampu untuk menyempurnakan keterbatasan dari penelitian. Keterbatasan dalam penelitian ini adalah pengambilan data angket respon dan tes hasil belajar dilakukan secara online. 3)
Bagi guru pembelajaran dapat dijadikan model pembelajaran kooperatif sebagai alternatif model pembelajaran yang relevan selain pembelajaran konvensional sehingga dapat membantu siswa dalam menyelesaikan soalsoal yang berkaitan dengan hasil belajar kognitif siswa salah satunya dengan model pembelajaran role playing berbantuan media video dapat diterapkan dalam pembelajaran IPA di kelas, karena dengan pembelajaran ini dapat meningkatkan hasil belajar kognitif siswa. 4) Bagi peneliti selanjutnya sebaiknya melakukan uji validitas konstruk dan reliabilitas pada angket respon siswa agar angket tersebut benar-benar layak digunakan dalam penelitian.

\section{UCAPAN TERIMAKASIH}

Ucapan terimakasih disampaikan kepada Kepala Sekolah, guru, dan siswa kelas IV SD Torsina III Singkawang sehingga penelitian ini dapat dilakukan dengan baik. Kemudian ucapan terimakasih juga disampaikan kepada STKIP Singkawang yang telah memfasilitasi peneliti dalam menyelesaikan artikel ini.

\section{DAFTAR RUJUKAN}

Adriana, A. (2016). Pengaruh Penerapan Model Pembelajaran Kooperatif dengan Tipe Role Playing Terhadap Minat dan Hasil Belajar IPA Pada Materi Makhluk Hidup dan Lingkungan Kelas IV SD Inpres Dekai Kabupaten Yahukimo. IImu Pendidikan, 4(1).

Anderson, L. W., \& Krathwohl, D. R. (2010). Pembelajaran, Pengajaran, dan Asesmen, Revisi Taksonomi Bloom. Pustaka Pelajar.

Ardi. (2016). Pengaruh Penerapan Model Pembelajaran Kooperatif Dengan Tipe Role Playing Terhadap Minat dan Hasil Belajar IPA Pada Materi Makhluk Hidup Dan Lingkungan Kelas IV SD Inpres Dekai Kabupaten Yahukimo. Jurnal IImu Pendidikan Indonesia, 4.

Aris, S. (2014). Model Pembelajaran Inovatif dalam Kurikulum 13. Ar-Ruzz Media.

Azhar, A. (2013). Media Pembelajaran. Raja Gratindo Persada.

Darmojo, H., \& Kaligis, J. R. F. (2002). Pendidikan IPA II. Depdikbud.

Hamzah. (2014). Kperencanaan dan Strategi Pembelajaran. Raja Grafindo Persada.

Hidayati. (2002). Pendidikan IImu Pengetahuan di Sekolah Dasar. FIP UNY.

Imas, K., \& Berlin, S. (2015). Ragam Pengembangan Model Pembelajaran Untuk Peningkatan Pfofesionalitas Guru. Kata Pena.

Juminten, B., \& Siregar, T. (2019). Metode Pembelajaran Role Playing dalam 
Meningkatkan Keaktifan dan Hasil Belajar IPA. Pada Materi Pertumbuhan Makhluk Hidup. UNCEN. IImU Pendidikan Indonesia, 7(2).

Kurniasih. (2015). Ragam Pengembangan Model Pembelajaran Untuk Peningkatan Profesionalitas Guru. Kata Pena.

Linda, N., Sukmanasa, E., \& Pratama, M. Y. (2019). Pengguan Media Pembelajaran Video Terhadap Hasil Belajar Siswa SD. $3(2)$.

Mariana, Alit, I. M., \& Wandi, P. (2009). Hakikat IPA dan Pendidikan IPA. Pusat Pengembangan dan Pemberdayaan Pendidikan dan Tenaga Kependidikan IImu Pengetahuan Alam (PPPPTK IPA).

Purwanto. (2010). Evaluasi Hasil Belajar. Pustaka Pelajar.

Sugiyono. (2018). Metode Penelitian Pendidikan Kuantitatif, Kualitatif dan R\&D. Alfabeta.

Sutikno. (2014). Metode \& Model-Model Pembelajaran Menjadikan Proses Pembelajaran Lebih Variatif, Aktif, Inovatif, Efektif, dan Menyenangkan. Holistica. 